\title{
THE EROSION OF COMMUNITY RIGHTS TO INTELLECTUAL PROPERTY: AN ASIAN PERSPECTIVE*
}

\author{
Naazima Kamardeen**
}

\begin{abstract}
[T] here would be no plant breeders in long white coats working on experimental farms if it were not for the prior knowledge gained from rural communities. Indigenous knowledge is not only the foundation of modern science in this and many other fields... it is also what could be described as the reference and referral centre for modern plant breeding. ${ }^{1}$
\end{abstract}

\section{INTRODUCTION}

The TRIPS agreement (Trade Related Aspects of Intellectual Property Rights Agreement) under the World Trade Organization (WTO) regulates the protection of intellectual property rights by those states that are its members.

The protection of such rights has led to fierce differences of opinion, heated debates and much name-calling between the nations of the developed world and those of the developing world. This was very clearly evidenced in the disagreement in the pharmaceutical sector, brought into focus by the HIV/AIDS epidemic; it called for swift action by the countries of Africa, where the disease is most prevalent. The countries could not afford to pay the high prices for the treatment available, and looked to cheaper generic solutions to help millions of people fight the disease. The action almost created a rift among the membership, and it was only in the 2001 Doha Ministerial Conference that the problem was addressed.

The next area where discord is already rife is one with enormous implications for the future - a future where greater power is found in smaller units. This is the

\footnotetext{
* This paper shared the Sata International Law Prize 2005 with that of Jaemin Lee, which appears in this volume.

** LL.B (Hons) (Colombo); LL.M (Georgetown); Attorney-at-Law (Sri Lanka); Lecturer, Faculty of Law, University of Colombo.

${ }^{1}$ Sahai, Suman (ed.), Bioresources and Biotechnology: Policy Concerns for the Asian Region (New Delhi: Gene Campaign, 1999), at 132.
}

Asian Yearbook of International Law, Volume 12 (B.S. Chimni et al., eds.)

(c) 2007 Koninklijke Brill NV. Printed in The Netherlands, pp. 83-108. 
field of bio-technology. It has been regarded as the "newest, most dominant technology of our times". 2

Section 5 of TRIPS extends patent protection to certain living beings, and asks members to provide patent or "patent like" protection for such beings. Article 27 (3) (b) qualifies this by providing that members may either grant or refuse patent protection for plants and animals. However, it also provides that members must provide patent protection for micro-organisms. Further, it mandates that plant varieties should be protected by patents or by an effective sui generis system, or by a combination of both.

Apart from the contentious issue of whether life forms should be patented at all, one of the inherent problems associated with this area is that the term sui generis has not been defined. Also, many developing countries such as Sri Lanka have no effective Intellectual Property systems in place; they do, however, have a large variety of traditional crops that have been bred and developed by farmers as well as by public-funded research institutes. These are available in the public domain and do not "belong" to anyone in particular. ${ }^{3}$ Conventional notions of property ownership, modelled along the lines of individual-style ownership, are not appropriate in a field where community ownership has been the norm. TRIPS will thus create a clash between concepts of individual ownership, on the one hand, and community ownership, on the other; it will force certain countries to abandon the latter in favour of the former, or risk forfeiting the right to use the product or process.

This paper will examine the various approaches that could be taken by developing countries to provide to plant and animal life protection that will conform to TRIPS, and yet be within the framework of the laws currently in place. The feasibility of these approaches will be analyzed, with a view to identifying the most effective one. It will also consider how the rights of indigenous communities can be safeguarded using TRIPS, as the world moves ever closer to an order based on WTO rules.

\section{BACKGROUND AND INTRODUCTORY REMARKS}

\subsection{The WTO and its importance in the field of intellectual property}

What we regard today as intellectual property is essentially the product of human intellect. Its intangible nature has resulted in the remaining unrecognized of its true worth and unappreciated until relatively recently. Nevertheless, modern humans appear to have been able to recognize those rights as also being proprietary, and has sought to safeguard them in almost the same way as a tangible property interest is safeguarded: by identifying them, and by providing for a means by which the right-holder

\footnotetext{
2 Idem, at 122.

${ }^{3}$ Gunawardene, Jagath, The Draft Act to Provide Protection for New Plant Varieties (Breeders' Rights) (Briefing paper published by the Law and Society Trust Colombo under the Regional Program on Farmers' Rights to Livelihood initiated by the South Asia Watch on Trade, Economics and the Environment (SAWTEE), 2003), at 2.
} 
can, to the exclusion of others, hold and enjoy them. Within this broad area identified as 'intellectual property' lie subdivisions such as patents, trademarks, and copyrights.

Intellectual property has become as valuable a commodity as a tangible good or service, hence its importance in world trade. Although there had been prior efforts to codify and protect intellectual property ${ }^{4}$ it was not until 1994 that intellectual property rights were included in any world trade forum. This happened at the conclusion of the Agreement on the Trade-Related Aspects of Intellectual Property Rights (TRIPS) as part of the Uruguay Round of multilateral trade negotiations under the General Agreement on Tariffs and Trade (GATT). After the World Trade Organization (WTO) succeeded GATT, the obligations under the TRIPS now form part of the WTO.

The WTO is an organization that embodies the new world order - the rule of the economically powerful. Members join primarily through self-interest, and the procedure for the settlement of trade disputes acknowledges the reality of a marketdriven world. In contrast to the International Court of Justice (ICJ), the dispute settlement body of the United Nations, which admits only States as parties to disputes before it, and the GATT, which allowed a country to "block" an adverse decision, the Dispute Settlement Understanding (DSU) of the WTO is ruthlessly efficient: it allows the victor to force the losing party into compliance by threatening to take retaliatory measures in any sector, not merely in the sector in which the dispute arose. In order for this to be of any real concern, the threat of the loss of market access or the tariff barrier (or indeed any other form of punishment) must be significant enough to frighten the losing party into compliance, and it is submitted that only countries with enough economic clout can do so. Hence, the WTO remains very much a rich person's club.

It has been argued that pharmaceutical and other high-tech industries were behind the proposal to link Intellectual Property Rights (IPRs) to trade in the first place. ${ }^{5}$ With the growth of technology as an important factor in international competition, and with the challenge offered by the newly-developing countries, the leadership of US firms in high-tech areas was eroding. Further, piracy and counterfeiting was seen to be another reason for a decline in productivity and competitiveness. This perception caused many of the industrial lobbies, including the software and pharmaceutical sectors, to pressure the US government to link IPRs with trade, to ensure that the sectors could avoid piracy and could also secure high returns on their research and development. ${ }^{6}$

With TRIPS falling under the purview of the WTO, it was anticipated that the rules applying to the WTO would necessarily also apply to the manner in which members resolved their intellectual property disputes. Since the WTO enjoys almost

\footnotetext{
${ }^{4}$ Namely, the Paris Convention for the Protection of Industrial Property of March 1883, and the Berne Convention for the Protection of Literary and Artistic Works of 1886. By incorporation, they now form part of members' obligations under the WTO.

${ }^{5}$ Correra, Carlos M., Intellectual Property Rights, the WTO and Developing Countries - The TRIPS Agreements and Policy Options (New York: Zed Books; 2000), at 4.

${ }^{6}$ Ibid.
} 
world-wide membership, it is apparent that TRIPS is now a force to be reckoned with. Further, it has proved to be an excellent means by which IPRs can be protected. However, a closer analysis reveals that the playing field is far from even. Developing countries' share in world Research and Development (R\&D) expenditures is a mere four per cent of total R\&D expenditure worldwide. Further, it has been estimated that 95 per cent of all patents granted in the United States between 1977 and 1986 were given to applicants from ten developed countries. Developing countries constituted less than two per cent. ${ }^{7}$ Since it is largely the developed countries who are the major players in the IPR field, it is easy to see whose interests are being safeguarded by such measures. As for the success of the TRIPS agreement, it has been shown that a positive correlation exists between the increase in exports from the US, and the strengthening of patent protection in developing countries. ${ }^{8}$

\subsection{The TRIPS agreement: a broad overview}

The agreement seeks to confer a wide variety of rights on the owners of intellectual property. Of the provisions in TRIPS, Articles 3 and 4 deserve special mention, and make up the core of the entire agreement. Article 3 calls for "National Treatment", whereby members must afford to foreigners treatment that is no less favourable than that which it affords to its own nationals with regard to the protection of intellectual property. Article 4 provides, subject to certain exceptions, that any special privileges granted by a member to any country (Most Favoured Nation, or MFN, Treatment) will automatically extend to other countries as well. The effect of these two provisions is to ensure that members do not draft intellectual property laws that give greater protection to domestic than to external players, and also that smaller regional groups do not seek compromises among themselves.

\subsection{The North-South dimension of TRIPS}

TRIPS has been viewed as an agreement that seeks to raise the standards of protection in developing countries to the level of those in developed countries. ${ }^{9}$ While TRIPS has necessitated changes to the Intellectual Property regime of almost every country, the more drastic changes will have to be made within the laws of the developing countries, many of which prior to TRIPS had no comprehensive Intellectual Property laws. For some developing countries, TRIPS covers new subject matter, among them product patents for food, pharmaceuticals, and micro-organisms. ${ }^{10}$

\footnotetext{
7 Ibid., at 5 .

8 Ibid., at 6.

9 Watal, Jayashree, Intellectual Property Rights in the WTO and Developing Countries (Netherlands: Kluwer Law International, 2001), at 2-3.

10 Ibid., at 4.
} 
It has been argued that there has been a North-South battle with regard to TRIPS. ${ }^{11}$ One of the most obvious factors is the difference in the respective levels of development of each sector, and the fear of the South that TRIPS will become yet another tool for Northern supremacy. The battle could also stem from an ideological difference in the interpretation of what is meant by the ownership of intellectual property. In the Western world, intellectual property is an extension of ordinary property, and embodies a private ownership interest. However, in many areas of the developing world, and especially in indigenous communities, intellectual property rights are rights claimed by communities as a whole, over their cultural knowledge. ${ }^{12}$ Hence, it is a community right, as opposed to a private right. This community-owned entity is therefore incapable of being owned or enjoyed in the same sense that a private right can, and this remains the chasm between the developed and the developing worlds.

\section{THE KEY AREAS OF THE DEBATE}

The two main substantive areas in which the North-South debate will be examined are the pharmaceutical sector, where an understanding has already been reached, and the bio-technical sector, where trouble is now beginning to brew. The debate over the pharmaceutical sector will be revisited for the purposes of establishing a pattern of facts, then drawing upon those lessons as a suggestion of how (or how not) to resolve future problems.

\subsection{The pharmaceutical industry and its lessons}

\subsubsection{The WTO and access to medicine}

Article 27 of the TRIPS agreement requires each WTO member to make both product and process patents available for any inventions in all fields of technology, provided that they are new, involve an inventive step, and are capable of industrial application. Further, governments will not be able to discriminate with respect to the enjoyment of patent rights based on the place of invention, the field of technology, and whether products are imported or locally produced. ${ }^{13}$ Article 27 (2) provides for a few limited instances in which patents may be denied. These include the protection of human, animal or plant life or health, serious prejudice to the environment, and also on grounds of public policy and morality. Further, diagnostic, thera-

\footnotetext{
${ }^{11}$ In this paper, the terms "developed countries" or the "North", and "developing countries" or the "South" do not necessarily denote geographical dimensions, but are used to define the difference between those who advocate greater IPR protection and those who do not.

${ }_{12}$ Greaves, Tom (ed.), Intellectual Property Rights for Indigenous Peoples - A Sourcebook (OK, USA: Society for Applied Anthropology, 1994), at ix.

13 Article 27(1).
} 
peutic, and surgical methods for the treatment of humans and animals may also be excluded from patentability. ${ }^{14}$

The effect of all this is to include many fields, among them pharmaceuticals, as pointed out specifically in the Congress's Statement of Administrative Action (SAA) on the Uruguay Round Trade Agreements. ${ }^{15}$ The TRIPS agreement makes special provisions for those countries that do not yet have systems of patent protection in place for the specific areas of pharmaceutical, agricultural and chemical products. Notwithstanding the concessions allowed in Part VI, ${ }^{16}$ those members should immediately provide an interim system that permits patent applications for these products to be filed. ${ }^{17}$ The date of filing gives priority for application purposes. Further, the criteria for patentability should be those of the time when the application was filed. ${ }^{18}$ In addition, the country must provide exclusive marketing rights for a period of five years after the product receives marketing approval, or until a patent is rejected or granted, whichever period is shorter. ${ }^{19}$

The US used these provisions against India, and obtained a decision in its favour, mandating that India was in violation of its obligations of Articles $63,{ }^{20} 70.8^{21}$ and $70.9^{22}$ of TRIPS by not having a valid mailbox system in place. ${ }^{23}$ As for the scope of the protection, Article 28 specifies that a patent will give the holder the right to exclude others from making, using, offering for sale, selling, or importing the product. Hence, for the pharmaceutical industry at least, the agreement is a foolproof safeguard.

\subsubsection{Developments prior to Doha}

Prior to the Doha round, several developing countries had discovered that their access to medicines to combat the deadliest of diseases was being hampered severely by TRIPS. This prompted Zambia, on behalf of the African Group, to submit a request for a new item called Intellectual Property and Access to Medicines to be placed on the Council's agenda. ${ }^{24}$ Accordingly, the Council discussed this matter, focusing on two main issues, namely, the interpretation of the provisions of the TRIPS

14 Emphasis added. See Article 27(3)(a).

15 H.R. Doc. 103-316, 103d Cong., Sess. (1994).

16 Developing countries are allowed a grace period of a total of five years and least-developed countries a total of ten years to implement their obligations under TRIPS.

17 Article 70(8)(a).

18 Article 70(8)(b).

19 Article 70(9).

20 This deals with the transparency obligation, whereby members are required to notify the Council of any changes they have made in their laws.

21 The "mailbox rule", ns. 17 and 18.

22 The grant of exclusive marketing rights. See n. 19.

23 See India - Patent Protection for Pharmaceutical and Agricultural Chemical Products, WT/ DS50/R.

24 Document IP/C/M/30, paras. 229-252, discussed in Gervais, Daniel, The TRIPS Agreement: Drafting History and Analysis, 2nd edn. (London: Sweet and Maxwell, 2003), at 42. 
agreement to clarify the flexibility that members were afforded, and the relationship between the TRIPS agreement and affordable access to medicines. ${ }^{25}$

The Council received two papers on the matter. One was from the EC, and the other was from a group of developing countries, including the African Group, Brazil, India, and Sri Lanka. ${ }^{26}$ The concerns embodied in each paper reflected the concerns of those countries as representing the North and South. The EC paper suggested that Articles 30 and 31 be interpreted as narrowly as possible, so as not to curtail the rights of patent holders except in cases of "national emergency and other situations of extreme urgency". ${ }^{27}$

In contrast, the paper submitted by the developing countries suggested that the TRIPS agreement provide the "broadest flexibility" in allowing parallel imports and compulsory licenses. While the EC would have interpreted Article 31 (f) as prohibiting the supply to foreign markets, the developing countries were of the view that Article 31 (f) did not prevent the grant of compulsory licenses to supply foreign markets; they also felt that members were free to determine the grounds for granting compulsory licenses. ${ }^{28}$

Article 31 does not specifically mention the words "compulsory license"; however, this is the interpretation that can be drawn from the reading. Further, Article 31 provides for the use of the patent without authorization in cases of "national emergency or other circumstances of extreme urgency". It fails, nevertheless, to define these terms.

Following the discussions, it was agreed that the Council should take a more prioritized approach to the matter, focusing on the objectives and principles of TRIPS, as laid out in Articles 7 and 8 of the Agreement. Article 7 specifies that the

$[\mathrm{P}]$ rotection and enforcement of IP rights should contribute to the promotion of technological innovation and to the transfer and dissemination of technology, to the mutual advantage of producers and users of technical knowledge and in a manner conducive to social and economic welfare, and to a balance of rights and obligations.

Article 8, which deals with principles, allows members to take reasonable steps consistent with the TRIPS agreement in order to prevent both the abuse of IP rights by the holders and the unreasonable restraint of trade, as well as the international transfer of technology. Two other matters were also identified as being of importance:

25 Gervais, op. cit., n. 24, at 42.

26 Ibid. The complete list includes Barbados, Bolivia, Cuba, the Dominican Republic, Ecuador, Honduras, Indonesia, Jamaica, Pakistan, Paraguay, the Philippines, Peru, Thailand, and Venezuela.

27 Ibid. Article 30 states that members may provide limited exceptions to the rights conferred by a patent, provided that those exceptions do not unreasonably prejudice the rights of the patent holder. Article 31 provides for the unauthorized use of a patent, subject to a long list of provisions. These include, in Article 31(f), that such use shall be "authorized predominantly for the supply of the domestic market of the member authorizing such use".

28 Ibid., at 43. 
the provisions relating to compulsory licensing, and the provisions relating to parallel imports.

\subsubsection{The South Africa AIDS case}

In 1997, South Africa, faced with an HIV/AIDS crisis of epidemic proportions, drafted a new Medicines Act. ${ }^{29}$ It gives the Health Minister the powers to override patent laws in a health emergency. Of particular importance is section $15 \mathrm{C}$, which empowers the Health Minister to allow compulsory licensing and parallel imports.

Over 39 pharmaceutical companies filed action against the government of South Africa on the basis that the law violated its obligations under TRIPS. ${ }^{30}$ However, after three years, due to "an extremely high amount of international pressure" ${ }^{31}$ the case was eventually withdrawn. This incident served to remind the membership that a workable solution had to be found as soon as possible.

\subsubsection{The Doha round and the pharmaceuticals debate}

A separate declaration on TRIPS and public health was one of four issues on the Doha agenda. This separate Declaration ${ }^{32}$ affirmed what had already been said in the main agreement, namely, that the TRIPS agreement should be interpreted in a manner that does not prevent members from taking steps to protect public health. It recognized "the gravity of the public health problems affecting many developing and least developed countries, especially those resulting from HIV/AIDS, TB, malaria and other epidemics". Veering away from the view that TRIPS was an instrument for the protection of private rights, it went on to say that "we stress the need for the WTO agreement on TRIPS to be part of the wider national and international action to address these problems."

In paragraph 4 it states that "TRIPS does not and should not prevent members from taking measures to protect public health... we affirm that TRIPS can and should be interpreted and implemented in a manner supportive of WTO members' rights to protect public health and, in particular, to promote access to medicines for all." It authorized members to use the provisions in TRIPS that provide flexibility for this purpose. Paragraph 5 identifies some of them as including the rights to grant compulsory licenses and to determine what constitutes a "national emergency or other circumstances of extreme urgency". HIV/AIDS TB and malaria or other epidemics are considered to be "a national emergency or other circumstances of extreme urgency".

Two specific tasks were also set out. The TRIPS council had to find a solution to the problems that developing countries may face in making use of compulsory

\footnotetext{
29 Medicines and Related Substances Control Amendment Act 90 of 1997. ftp://ftp.hst.org.za/pubs/ govdocs/acts/1997/act90.pdf.

30 Reported at http://www.cptech.org/ip/health/sa/pharma-v-sa.html.

31 Ibid., at para. 2.

32 Document WT/MIN(01)DEC/2.
} 
licenses if they have little or no pharmaceutical manufacturing capacity. They were required to report to the General Council on this by the end of 2002. In addition, Least-Developed Countries (LDCs) were given time till 1 January 2016 for the implementation of the rights related to pharmaceuticals, with the option of postponing them further. ${ }^{33}$ LDCs were also exempt at least until 1 January 2016 from the obligation to provide exclusive marketing rights as provided by Article 70(9). ${ }^{34}$

\subsubsection{Responses to Doha}

On 30 August 2003, the General Council adopted the Decision on the Implementation of paragraph 6 of the Doha Declaration. ${ }^{35}$ It acknowledges that "exceptional circumstances exist justifying waivers from the obligations set out in paragraphs (f) [domestic market use] and (h) [remuneration to right-holder] of Article 31 of the TRIPS agreement with respect to pharmaceutical products." It defines "pharmaceutical product" as including a component required to address public health problems. ${ }^{36}$

The Decision also sets out the procedure to be followed when importing such products into the country where it is needed. First, the importing member should notify the TRIPS Council that it intends to import a specific quantity of a named drug, and that it lacks the manufacturing capacity in the pharmaceutical sector. It should also confirm that it has granted or intends to grant a compulsory licence, where the pharmaceutical product is patented in its territory. ${ }^{37}$ Further, the exporting member should issue a compulsory licence containing certain conditions as to the amount to be produced, as well as the undertaking that the final destination of the products shall be only those markets of the members who notified the Council of their needs. $^{38}$

The Decision makes provision for adequate remuneration for the products, taking into consideration their economic value in the importing country. ${ }^{39}$ Members are also encouraged to prevent re-exportation of these products. ${ }^{40}$

Paragraph 11 says that these provisions will be replaced by the subsequent amendments to the TRIPS agreement, due to begin in December 2003. However, these amendments have not yet been agreed upon.

When analyzing this decision, and the effect it has upon TRIPS, one realizes that little has changed. The interpretation sought to be given takes a middle path

\footnotetext{
33 Document IP/C/25 entitled Extension of the Transition Period under Article 66.1 of the TRIPS Agreement for Least-Developed Country Members for Certain Obligations with Respect to Pharmaceutical Products.

34 Document WT/L /478 entitled Least-Developed Country Members - Obligation under Article 70.9 of the TRIPS Agreement with Respect to Pharmaceutical Products.

$35 \mathrm{WT} / \mathrm{L} / 540$.

36 Ibid., para. 1.

37 Ibid., para. 2(a).

38 Ibid., para. 2(b).

39 Ibid., para. 3.

40 Ibid., para. 4.
} 
between allowing members to issue compulsory licences, and prohibit them from accessing medicines altogether. However, much remains in the hands of individual nations and the manner in which they seek to interpret these provisions. The EC, in their Communication on this decision, issued on 17 November $2003,{ }^{41}$ welcomed the decision and pledged to help to implement it. They stated that "to make the system really work, members will have to refrain from overly restrictive interpretations of the decision which could affect its efficiency." The US issued a statement on paragraph 6 of the Doha Declaration and TRIPS. ${ }^{42}$ Although it commences with the words "we are committed to helping countries that are experiencing public health crises", it goes on to take a hard stand on the issue, conceding only the minimal divergence from TRIPS. For example, it says "Compulsory Licenses are appropriate, but it must be borne in mind that these are the exceptions, rather than the norm". It says that measures should be taken to see that the rights granted under this measure are not exploited.

The US cannot afford to deviate far from this position, considering that a hard-line approach was taken when the implementation of the Bill for the Uruguay Round Trade Agreements was debated before Congress. The SAA contends that TRIPS mandates that "WTO countries must make patent protection available for essentially all fields of technology, including pharmaceuticals...". ${ }^{43}$ Further, the SAA interprets the conditions under which members may make unauthorized use of a patented invention as "stringent". ${ }^{44}$ The US took this very attitude in many of the discussions following Doha, maintaining that the exceptions to TRIPS should be limited to diseases such as HIV/AIDS, TB, malaria, and other serious, infectious epidemics. ${ }^{45}$ It alone opposed the draft of 16 December 2002 proposed by the Council chairman, arguing that the scope of disease coverage went beyond what was originally agreed to in Doha. ${ }^{46}$ This caused considerable delay, as the members realized that US support was needed if the proposal was to work; they could not proceed without it. The US was also not amenable to an EU proposal that attempted to list a specific number of diseases, and provide for a mechanism whereby developing and leastdeveloped countries could appeal to have further diseases added to the list. ${ }^{47}$

One of the dangers of having the pharmaceutical industry exert such great influence over the ultimate outcome is the fact that many of these companies are based in the Western world. Today, diseases are also polarized in terms of geography, and the serious, infectious epidemics mentioned exist largely in the developing world. Having conquered these diseases, the pharmaceutical companies have turned to finding cures for the more cosmetic problems of those in the developed world. Noting this,

\footnotetext{
41 http://www.wto.org/english/tratop_e/trips_e/trips_e.htm.

42 http://www.wto.org/english/tratop_e/trips_e/trips_e.htm.

43 Statement of Administrative Action, 7(a).

44 Statement of Administrative Action, 7(b).

4519 BNA International Trade Reporter (ITR) 2162, 12/19/02.

4620 ITR 7, 02/13/03.

4720 ITR 8, 02/20/03.
} 
the World Health Organization agreed on 28 May 2003 to establish a body to be responsible for examining the impact of IP rights protection on the development of new drugs. ${ }^{48}$ The resolution calls for the collection of data and an analysis of IP rights, innovation, and public health issues. It will also look into identifying funding and other incentives for the development of new medicines to fight diseases that mainly affect developing countries.

This action plan confirms the fact that the WHO has realized that pharmaceutical companies no longer have the entire world's health interests at heart. For example, the resolution noted that, out of a total of about 1,400 new products developed by the pharmaceutical industry between 1975 and 1999, only 13 were for tropical diseases and just three were for TB, both endemic in the developing world. ${ }^{49}$ The WHO resolution also calls for the newly established body to analyze the "pharmaceutical and public health implications of relevant international agreements" such as TRIPS, so that governments "are able to maximize the positive and mitigate the negative impacts of those agreements." 50

\subsubsection{Concluding remarks}

The course of events leading up to Doha, and the subsequent negotiations and documents that have followed, have displayed only a grudging willingness by all parties to submit to certain concessions they perceive as being unfavourable to them. While bargaining and haggling are inevitable parts of any trade negotiation, they are not a productive means of negotiation on issues of public health, given that these can have long-term implications. Hence, a hard-nosed attitude will not work optimally in this area. Further, even though the pharmaceutical sector wields considerable influence in the deals that are ultimately agreed, the legitimacy of the sector's concern is at question, given the data showing that they are really no longer interested in the diseases that afflict the developing world, where the larger (although poorer) part of the world's population lives. Also, the traditional herbs and medicinal plants owned by communities as a whole are at risk of being patented and used by these companies as well. The pharmaceutical sector has established for itself an unenviable reputation, thus the conclusion may easily be reached that it will not strive to use communityowned herbs and plants in a manner benefiting society as a whole, but will, rather, attempt to exclude these communities from using them altogether.

It is also interesting to evaluate the approach taken in interpreting obligations under the TRIPS agreement in the light of the standards advocated by public international law. According to Article 31 of the Vienna Convention on the Law of Treaties, treaties

\footnotetext{
4820 ITR 23, 05/06/03.

49 Ibid.

50 Ibid.
} 
[S]hall be interpreted in good faith in accordance with the ordinary meaning to be given to the terms of the treaty in their context and in the light of its object and purpose. ${ }^{51}$

When the Doha Declaration, and the events that followed it, are examined, it would seem as if the member states to the WTO have forgotten this basic premise of public international law. The haggling over the interpretation of words indicates that certain countries are unwilling both to interpret these terms in good faith and to give to them their ordinary meaning, because it does not serve their own selfish interests to do so. The example of the pharmaceutical sector has shown us that, instead of "reducing tension by reaching strengthened commitments to resolve disputes" $" 52$ there has in fact been greater tension and less commitment. The pattern of behaviour, as evidenced by the pharmaceutical industry, does not augur well for the newer areas in which conflicts still exist, and where the major issues have as yet not been resolved.

\subsection{The patenting of plant and animal life: Article 27 (3) of TRIPS}

Article 27(3) of TRIPS specifies those products and processes that are excluded from patentability. Article 27(3)(b) lists plants and animals other than micro-organisms, and essentially biological processes for the production of plants or animals other than non-biological and microbiological processes. However, members are required to protect plant varieties either by awarding patents or by an effective sui generis system - or by any combination of these. This means that micro-organisms produced by humans using inventive methods may be patented, along with processes that are non-biological and microbiological. The provision comes very close to the fine line that exists between life and non-life forms. The issues raised by the provision and its implications cover such areas as the ethical debate over the patenting of life forms, the definition of the term 'life forms' itself, the appropriation of traditional knowledge, farmers' rights, and the definition of a sui generis system, to name but a few. The subsequent portion of the paper will consider each of these issues, as well as the legal framework within which solutions are being sought.

\subsubsection{The definition of life forms: what may be patented}

Patent law has drawn a distinction between inventions and discoveries, and has permitted only inventions to be patented. However, the boundaries of what would be termed "inventions" have been pushed back by genetic engineering; the result is that today, it is up to the interpretation given by the particular country that decides what is patentable or not. ${ }^{53}$ Such a circumstance leads to various and different

\footnotetext{
51 Vienna Convention on the Law of Treaties, 1969, available at http://www.walter.gehr.net/ wvkengl.html

52 TRIPS Agreement, Preamble.

53 The TRIPS Agreement does not define this term, leaving it to each country to decide.
} 
standards. Developed nations and entities such as the US, the EU, and Japan grant patents to substances that are new in the sense that they were not previously available to the public, as opposed to being new in the sense that they have never existed before. ${ }^{54}$ The European Patent Convention provides that even if biological material has previously occurred in nature, it shall be patentable if it is isolated by means of a technical process. ${ }^{55}$ The EU has also passed a Directive on the Legal Protection of Biotechnological Inventions allowing for the patenting of microbiological processes. ${ }^{56}$ This entails that in certain developed countries, the novelty requirement is interpreted to mean that "new" is no longer "not pre-existing", but "novel" in a prior art sense. ${ }^{57}$ The interpretation, it is submitted, brings inventions closer to the realm of discoveries. Hence, with regard to biological materials, it allows for the patenting of genes, thus giving the right-holder almost limitless rights with regard to the use of that gene in genetic engineering. ${ }^{58}$ However, developing nations are unwilling to go so far. Mexico and Brazil, for example, have excluded the patentability of all genetic materials. The Brazilian patent law of 1996 denies patents to living beings or "biological materials found in nature", even if they are isolated. This also includes the "genome or germplasm" of any living being. ${ }^{59}$

It is clear that such divergences in interpretation will only cause more confusion and division among the WTO membership, as each member seeks to have their own respective standards upheld. Countries with large R\&D sectors that have patented these micro-organisms are not going to give up the rights that they confer so easily. For example, it has been noted that patents with regard to cotton, corn, and soybean are being aggressively enforced and are being used to establish competitive advantage in the marketplace. ${ }^{60}$ However, granting patents in this area may actually have a counterproductive effect as the granting could block innovation and further research. It has been noted that "patents on genes of wide utilization in agriculture can block the development of new varieties in clear contradiction to the objectives for which the (patent) system was designed." ${ }^{\prime 61}$ These examples illustrate the fact that allowing the patenting of life forms does not in the long run serve society, but only the shortterm goals of a few interested parties.

\subsubsection{Should life forms be patented?}

The ethical question as to whether life forms should be patented at all is another issue, and one with which international trade does not concern itself. Today, many

\footnotetext{
${ }^{54}$ Correra, op. cit., n. 5, at 177-178.

55 EPC, Article 3.2.

${ }^{56}$ Article 4. Available at http://www.eu.int/eur-lex/pri/en/oj/dat/1998/1_213/1_21319980730en 0013002.pdf

57 Ibid.

58 Correra, op. cit., n. 5, at 178.

59 Ibid.

${ }^{60}$ Correra, op. cit., n. 5, at 182.

61 Ibid.
} 
countries would choose to answer the question from a commercial or financial standpoint, and very few have cited moral or ethical reasons for restricting the patenting of life forms. TRIPS does provide for exclusion from patentability based on moral grounds, ${ }^{62}$ yet again, the interpretation of what constitutes a moral ground is also left to the discretion of each country. The European Patent Office rejected the patentability of the Harvard "Oncomouse" based on moral grounds, but this decision was reversed by its Technical Board of Appeals. ${ }^{63}$ The patent for the oncomouse, issued in 1988, was the first transgenic animal patent to be issued. It must be borne in mind that the animal was to be used in the testing of cancer. It illustrates that the decisions are also difficult to make, probably due to the fact that the dividing line between what is moral and what is immoral in this area is becoming increasingly more blurred.

\subsubsection{Farmers' rights and intellectual property}

The debate on the patenting of life forms will reach its most crucial stage in the area of agriculture and Plant Genetic Resources (PGRs). The next section of the paper will discuss the importance of PGRs, and the impact of Intellectual Property rights in this field on the rights of farmers in developing countries, who have traditionally owned the intellectual rights over the plant varieties that they have developed, within their communities.

\subsubsection{The importance of the farmer as a developer of new seed varieties}

We are inclined to think of the farmer merely as a person who produces the food we eat. However, the farmer plays the important roles of grower, breeder, scientist, and researcher. Farmers do not merely use seeds; they help to conserve and improve new plant varieties. It has been noted that their activities "ensure crop evolution whereby new varieties arise through genetic recombinations, mutation and hybridization within and between cultivated and wild plant populations". ${ }^{64}$ Another important factor is that many of these traditional crops have been bred, developed, and kept alive by farmers and are available in the public domain. ${ }^{65}$ The contributions made by farmers to the development of plant diversity have been recognized by the International Undertaking on Plant Genetic Resources (IU). ${ }^{66}$ However, farmers are

\footnotetext{
${ }^{62}$ Article 27(2) states: "Members may exclude from patentability inventions, the prevention within their territory of the commercial exploitation of which is necessary to protect ordre public or morality, including to protect human, animal or plant life or health or to avoid serious prejudice to the environment, provided that such exclusion is not made merely because the exploitation is prohibited by domestic law".

${ }_{63}$ Correra, op. cit. n. 5, at 188.

${ }^{64}$ Brush, Steven, Providing Farmers' Rights through In Situ Conservation of Crop Genetic Resources (Report to the Commission on Plant Genetic Resources, University of California, 1994), cited in Correra, op. cit., n. 5, at 167.

${ }_{65}$ Gunawardene, op. cit. n. 3, at 2.

${ }^{66}$ Correra, op. cit., n. 5, at 167.
} 
frequently not viewed as plant breeders, with the result that another individual or organization may use the seed that has been preserved and developed by the farmer, add an inventive step to it, and patent it - with no benefit accruing to the farmer.

Also, the various legal instruments that govern this area send out mixed signals. While the Convention on Biological Diversity (CBD) has sought to establish rules on the access to genetic resources and on benefit sharing, $\mathrm{UPOV}^{67}$ has sought to limit the rights relating to such access. All of these will in turn have an impact on the way TRIPS is implemented. While plant breeders' rights seek to restrict access to certain protected varieties, it has been recognized that freer access is vital if the world's food demands are to be met. The Food and Agricultural Organization (FAO) had recognized that PBRs were not incompatible with its objectives of accessing and using PGRs for food and agriculture. ${ }^{68}$ UPOV's previous models had also allowed this, by permitting the use of protected varieties as the source material for further variation and the re-use by farmers of saved seeds. Both of these activities are regarded as important methods of diversity generation. However, the revision of UPOV, as well as the growing willingness to patent plant materials, has threatened the concept of free access to these resources.

In the negotiations of the IU, it has been stressed that access to PGRs for food and agriculture is essential for sustainable agriculture. The IU aims at a system of "shared access", whereby those participating in a multi-lateral system will be able to share in the benefits. There has also been concern that increased IP rights will make the exchange of this information difficult, if not impossible. ${ }^{69}$ Accordingly, certain countries may be unwilling to enter into a shared access regime if the genetic resources maintained and developed by their farmers and communities are to be appropriated by foreign companies, who will then patent those resources and prevent those very countries that supplied the original resources from having access to and using the protected material. This conflict has been described as follows:

The Third World farmer has a three-fold relationship with the corporations that demand a monopoly of life forms and life processes. Firstly, the farmer is a supplier of germplasm to TNCs [trans-national corporations]. Secondly, the farmer is a competitor in terms of innovation and rights to genetic resources. Finally, the Third World farmer is a consumer of the technological and industrial products of TNCs. Patent protection displaces farmers as competitors, transforms them into suppliers of free raw materials, and makes them totally dependent on industrial suppliers for vital inputs such as seeds. ${ }^{70}$

\subsubsection{Bio-piracy and bad faith}

67 The International Union for the Protection of New Varieties of Plants. See the discussion, infra.

68 Resolution 4/89, cited in Correra, op. cit., n. 5, at 168.

69 Correra, op. cit., n. 5, at 170.

70 Shiva, Vandana and Radha Holla-Bhar, "Piracy by patent: The case of the neem tree", in Mander, Jerry and Edward Goldsmith (eds.), The Case Against the Global Economy and For a Turn Toward the Local (San Francisco: Sierra Club Books, 1996), at 157. 
The current regime of IPR protection of genetic resources is also not equitable. Apart from the ethical issues already discussed, there are three other factors that merit consideration: first, a large number of patents have been granted on genetic resources obtained from developing countries, often without the knowledge and consent of those who possess these resources. This has led to charges of bio-piracy, which involve resources that are protected without further improvement. For example, researchers of Colorado State University were awarded a patent for quinoa without having added anything to it. ${ }^{71}$ Further, patents have also been granted for products based on plant materials and knowledge developed and used by local and indigenous communities, such as the cases of the neem tree, kava, and turmeric. A patent on turmeric granted to the University of Mississippi in 1993 was invalidated by the US Patent Office at the request of India's Council for Scientific and Industrial Research. ${ }^{72}$ Some of these patents are in direct violation of the laws that govern this area. For example, it has also been argued that the growing and marketing of "Texmati" or "Texbasmati" - the basmati grown in Texas - is a violation of the Geographical Indication provisions of TRIPS, as well as a direct violation of the CBD. It violates TRIPS because it assumes the name of the long-grained, fragrant rice grown in regions of India and Pakistan. It violates the CBD because it appropriates the ownership rights of India and Pakistan to the germplasm found in their territories. ${ }^{73}$

Secondly, some patents have been granted based on the function, and not on the structure, of the invention. This means that the invention is described on the basis of what it does, rather than its constituents. The result is a far wider scope than should be awarded; it restricts access by others to a wide segment of germplasm. For example, it has been noted that patents have been awarded for any genetic manipulation of cotton, regardless of the germplasm used, as well as a patent awarded to Lubrizol for sunflower seed, where the exact properties were not set out. ${ }^{74}$

Thirdly, certain entities have sought to register PBRs for resources that have been deposited in genebanks and are being held in trust for the international community. This should not be allowed under any circumstances, as it amounts to theft, pure and simple. The Consultative Group on International Agricultural Research (CGIAR) has called for a moratorium on granting IPRs on designated germplasm that are held in CGIAR's collections in research centres around the world. CGIAR has stated that such germplasm is held in trust for the world community and therefore should not be patented by anyone. ${ }^{75}$

All of these types of activities have increased the fear of developing countries, many of which are rich in bio-resources, that they will be at the losing end of the deal if IP rights are enforced and strengthened.

\subsubsection{The role of patents in restricting access}

71 US patent No. 5, 304 718, cited in Correra, op. cit., n. 5, at 172.

72 Correra, op. cit., n. 5, at 172.

73 Sahai, op. cit., n. 1, at 126.

${ }^{74}$ Correra, op. cit., n. 5, at 172.

75 Ibid. 
As mentioned before, access to PGRs is necessary for the continuous adaptation and improvement of plants for food and agriculture. Innovation in breeding activities takes place in an incremental manner, and is based on the modification of that which is already in existence. As long as there is access to these resources, the cycle that has been in place for hundreds of years can continue. The grant of IP rights, however, threatens to break the cycle and bring it to a complete standstill. According to Article 28 (1) (a) of the TRIPS agreement, patents relating to products confer the right to prevent third parties who do not have the patent holder's consent from "making, using, offering for sale, selling, or importing..." the product. Regarding process patents, the patentee, while preventing the use of the process, may also prevent the commercialization of a product obtained directly by that process. Hence, if a process to produce a plant is protected, the plant so created would also be protected. ${ }^{76}$

Further, while a patent-holder cannot exercise his/her rights in an area where the patent is not registered, the presence of a patent can prevent the importation of products containing the patented invention. Thus, the total exclusion of competitive products can be effected by the awarding of a patent. ${ }^{77}$ Such restrictive practices have resulted in seed companies' becoming increasingly inventive in their pursuit of monopolies, and have consolidated in perhaps the greatest threat to world food security: the creation of "terminator" technology.

\subsubsection{Terminator technology and farmers' rights}

An invention in genetic engineering, owned jointly by a US seed company, Delta and Pine Land, and the US Department of Agriculture, was granted a patent in $1998 .^{78}$ It was dubbed the "terminator" gene. The technology employed is known as Genetic Use Restriction Technologies (GURTS). This technology prevents the plant from producing its own seeds, ${ }^{79}$ or from growing properly unless a particular chemical is applied. ${ }^{80}$ The result of terminator technology will be that farmers can no longer save seeds for the subsequent season, as the life cycle of the seed has been terminated. The farmer has, furthermore, to use the fertilizer and chemicals advocated for the particular crop, as the crop will fail to grow or yield the optimum harvest unless those particular chemicals are applied. The possibilities of this technology are alarming, to say the least. The concept of a non-germinating seed is perhaps the worst-case of all scenarios, as it signifies a break in the cycle of life. On a more commercial level, it will force farmers to be dependent on the seed companies. The plight of the subsistence farmer in developing nations is even harsher. It is estimated that in developing nations, the tradition of saving seed from one cropping season

76 Ibid., at 176.

77 Ibid.

78 US patent no. 5,723,765.

79 These are called variety-GURTS or V-GURTS.

80 These are called trait-GURTS or T-GURTS. 
to the next, particularly in crops like paddy, is as high as 90 per cent or more. ${ }^{81}$ Also, once the farmer is dependent on a particular type of fertilizer or chemical, he has to buy it irrespective of the price. ${ }^{82}$ The monopolistic situation thus created serves only to make it harder for the farmer to continue with his livelihood.

There is no justification for GURT technology, save that it will bring economic benefits to those who own it. Further, GURT technology raises the fear that seeds incorporating V-GURTs will drift to traditional crops grown in neighbouring fields and render them sterile. In addition, farmers whose crops are affected by the V-GURT seeds could also find themselves in unwitting violation of the patent rights of the holder of the patent for the V-GURTS, even though they did not incorporate the seeds willingly. There have been reports of expanding V-GURT technology to include animals and insects. These remain largely unverified. ${ }^{83}$ In response to public concerns, Monsanto, one of the largest seed companies in the world, announced that it would not introduce V-GURT technology. However, none of the seed companies has abandoned V-GURT research; it has, furthermore, been reported that V-GURT technology is currently being used in the US.

At a more global level, the International Agricultural Research Centers (IARCs), supported by the CGIAR and the Rockefeller Foundation, have decided not to allow any terminator technology into their breeding material. India has followed, with a clause in its Protection of Plant Varieties and Farmers' Rights Bill which refuses protection to seeds and planting materials incorporating GURTs. Nevertheless, GURT technology remains a potential, and undeniably real, danger.

\subsubsection{The developing country farmer and the developed country farmer: the fundamental difference}

While GURT technology and the increased awarding of restrictive patents will affect farmers everywhere, their destructive potential is heightened with regard to the farmers in the developing world. Unlike farmers in developed nations, who are supported by subsidies from their governments, farmers in developing nations are subsistence farmers, and often have no savings to fall back on. Some even incur debt in order to buy the seed for the current planting season, and repay the debt only when the crop is harvested. There is no subsidy system to protect them, nor is there social security. Further, they are now unable to take out bank loans, as many banks will not lend to farmers on account of the latter's poor credit history. It is, quite literally, a suicidal situation. ${ }^{84}$

\subsubsection{Farmers' rights to traditional knowledge: sharing the benefits}

81 Sustainable farming systems through traditional plant genetic resources and indigenous knowledge based practice (2002) Helvitas, Sri Lanka, cited in Gunawardene, op. cit., n. 3, at 2.

82 For a discussion on this point, see Watal, op. cit., n. 9, at 162.

83 Watal, op. cit., n. 9, at 162.

84 In Sri Lanka, for example, the suicide rate among farmers is estimated to be the highest in the country. 
As mentioned above, a fundamental issue appears to be that concepts of ownership vary between North and South. Traditional communities have, for long years, practised the concept of community ownership. This stems from the notion that nature cannot be owned, and that crop varieties are sacred gifts from the Creator. ${ }^{85}$ However, today these communities have been forced to accept a world order where all property must be claimed and owned. If they are tardy in claiming their rights, they stand to lose them forever. Among the intellectual property rights held by traditional communities in their folk varieties are included the rights to the information encoded in their DNA as well as knowledge about production and use of their folk varieties. ${ }^{86}$

While it is true that farmers have a right to this knowledge, it is equally true that bio-technical companies, due to the vast resource bases to which they have access, are capable of extracting the maximum benefit from such knowledge. However, the issue seems to be that neither the companies nor the laws to which they subscribe appear to recognize the need to reward the farmers by sharing with them at least some of the benefits. As for benefit sharing, it has been noted that very few companies reciprocate towards the farmers by agreeing to share benefits when they are allowed to access genetic resources or traditional knowledge. ${ }^{87}$ The other method for protecting farmers' rights in this regard is through legislation, the next point for consideration.

\subsubsection{Legal responses to the issue of benefit sharing and the recognition of farmers' rights}

This section deals with the various legal instruments that have attempted to identify the issues and offer some solutions. As TRIPS ultimately rules, each of these will be compared with TRIPS to ascertain the level of validity of the principles in the face of TRIPS.

\section{The TRIPS agreement}

The TRIPS agreement is today the single most powerful legal document that affects both intellectual property and the rights of those who claim them. Interestingly enough, it contains no provisions that recognize either the concept of community ownership or the sharing of benefits among various interest groups such as farmers and breeders. It has been suggested that this might be covered by Article $39 ;{ }^{88}$ however, Article 39 deals with the protection of undisclosed information, and appears to pertain more closely to trade secrets than to traditional knowledge. A more bene-

\footnotetext{
85 Soleri, Daniela, David Cleveland et al, "Gifts from the Creator: intellectual property rights and folk crop varieties", in Greaves, op. cit., n. 12, at 21.

86 Ibid.

87 Watal, op. cit., n. 9, at 174.

${ }^{88}$ For a fuller discussion, see von Lewinski, S. (ed.), Indigenous Heritage and Intellectual Property: Genetic Resources, Traditional Knowledge and Folklore (Netherlands: Kluwer Law International, 2004), at 32.
} 
ficial option seems to be the sui generis protection system advocated by Article 27 (3), which asks members to provide for the protection of plant varieties either through the granting of patents or by an effective sui generis system, or by a combination of both. This topic was discussed in Doha, and the following statement was issued in the Ministerial Declaration: ${ }^{89}$

We instruct the Council for TRIPS, in pursuing its work programme including under the review of Article 27.3(b), the review of the implementation of the TRIPS agreement under Article $71.1 \ldots$ to examine, inter alia, the relationship between the TRIPS agreement and the Convention on Biological Diversity, the protection of traditional knowledge and folklore, and other relevant new developments... In undertaking this work, the TRIPS Council shall... take fully into account the development dimension.

However, to date, nothing has been forthcoming along these lines. It must be borne in mind that the Council has thus far been preoccupied with resolving the issues in the pharmaceutical sector, and has probably not created the opportunity to start on this one. Nevertheless, the problem has indeed been identified, and that is as much as may be expected, at least for the moment.

\section{The Convention on Biological Diversity (CBD)}

The CBD is one of the instruments opened for signature at the Rio Conference $;^{90}$ it addresses the economic rights and needs of indigenous people. The $\mathrm{CBD}^{91}$ highlights two important aspects of the debate: first, it recognizes that indigenous communities are dependent on biological resources. Preambular paragraph 12 mentions the "close and traditional dependence of many indigenous and local communities embodying traditional lifestyles on biological resources". Secondly, it recognizes the concept of benefit sharing. The same paragraph mentions the desirability of equitably sharing the benefits derived from the use of such traditional knowledge, innovations, and practices. These are, however, not embodied in the main text, and are helpful only in shaping the thought process behind the Convention. The operative section is Article 8(j): it calls for States to respect, preserve, and maintain such knowledge, and also calls on them to encourage the equitable sharing of the benefits arising from their utilization.

However, the CBD looks at the issue of benefit sharing from the perspective of conservation and the sustainable use of biological diversity, rather than from an intellectual property perspective. This is due to the fact that it is an environmental treaty, falling under the auspices of the United Nations Environmental Program (UNEP). Further, and more importantly, it is a UN document, subject to the lethargic and inefficient dispute settlement mechanism of the International Court of Justice (ICJ), which pales in comparison with the razor-sharp DSU of the WTO. WTO

\footnotetext{
89 Para. 19 of the Ministerial Declaration, WTO Doc. WT/MIN(01)DEC/W/1 of 14 November 2001.

90 The United Nations Conference on Environment and Development, held in Rio de Janeiro, 1992.

91 http://www.biodiv.org/convention/articles.asp.
} 
members know that they will face the risk of retaliation if they fail to comply with a DSB ruling; UN members need not heed the ICJ ruling since there is no risk of losing any trading advantages, and may feel obliged to comply only for the sake of international comity - not as compelling a reason as the loss of trading benefits. Also, since only States may be parties to any ICJ disputes, it functions less well than does the WTO, where States have greater responsibility for their trade decisions, and consequently, for the actions of the private individuals who operate under them.

\section{The World Intellectual Property Organization (WIPO)}

In 1998 the WIPO began to analyze the intellectual property aspects of traditional knowledge; in 2001 it issued a report. ${ }^{92}$ Apart from this, the WIPO proposes to provide training workshops in intellectual property for holders of traditional knowledge. It also proposes to conduct case studies and pilot projects on the interfaces between intellectual property and traditional knowledge. ${ }^{93}$ Since 2000, a special body, designated the Intergovernmental Committee on Intellectual Property and Genetic Resources, has been working on such topics as the development of model clauses for genetic resource contracts, work on a possible sui generis system for the protection of traditional knowledge, and the consideration of the Final Report on National Experiences with the Legal Protection of Expressions of Folklore. ${ }^{94}$ However, none of these efforts has as yet yielded any concrete measures in helping to protect the interests and needs of indigenous and local communities with regard to their traditional knowledge. ${ }^{95}$

\section{UPOV}

The International Union for the Protection of New Varieties of Plants, referred to commonly by the name UPOV,${ }^{96}$ seeks to promote plant breeding activities throughout the world, and to offer incentives for the creation of new and improved plant varieties. The criteria for protection under $\mathrm{UPOV}^{97}$ involve no inventive step, nor any showing of usefulness. Rather, they require only that the plant variety be commercially novel, ${ }^{98}$ distinctive, ${ }^{99}$ uniform ${ }^{100}$ and stable. ${ }^{101}$

\footnotetext{
92 WIPO, Intellectual Property Needs and Expectations of Traditional Knowledge Holders, 2001, http://www.wipo.int/globalissues/tk/report/final/index.html.

93 See e.g., WIPO/UNEP, The Role of Intellectual Property Rights in the Sharing of Benefits Arising from the Use of Biological Resources and Associated Traditional Knowledge, Selected Case Studies (Submission to the Executive Secretary of the Convention on Biological Diversity for consideration at the Fifth Conference of the Parties to the Convention on Biological Diversity, held at Nairobi, Kenya in May 2000).

94 Stoll, Peter-Tobias and Anja von Hahn, "Indigenous peoples, indigenous knowledge and indigenous resources in international law", in von Lewinski, op. cit., n. 88 at 30.

95 Ibid.

96 UPOV is the acronym of the French title.

97 http://www.upov.int/en/publications/conventions/1991/content.htm.

98 UPOV Convention 1991, Article 6.
} 
Since UPOV asks neither for inventiveness nor for usefulness, the standards are lower than are those for patent protection. This has been seen as beneficial to breeders, by allowing them to claim protection for plant varieties that are quite similar, without making drastic changes in their agronomic traits. ${ }^{102}$ Further, UPOV contains the "farmers' privilege" allowing the farmers to use saved seeds for future crops. Article 15 (2) permits the Contracting Parties to allow farmers to use protected varieties, provided that it is for propagating purposes, on their own holdings, and is the product of the harvest they have obtained by planting. Additionally, UPOV also allows the "research exemption" 103 whereby protected materials may be used as a basis for developing new varieties. It has been suggested that UPOV provides the best model of a sui generis system as envisaged by Article 27 (3) (b) of TRIPS. ${ }^{104}$ Some scholars argue that there are very few alternatives to UPOV. Since the establishment of a sui generis system that is actually effective could involve considerable amounts of time and money, a system beyond UPOV complying with the effectiveness required by TRIPS is considered "very unlikely". ${ }^{105}$ They believe that UPOV will probably become the global standard left unspecified by TRIPS. ${ }^{106}$

However, UPOV is not without its own flaws. It differentiates between farmers and breeders, as evidenced by the "farmers' privilege" section. This is contrary to the view taken in traditional communities, of farmers as breeders. If farmers are not breeders, then that role is presumably adopted by those who commercially exploit the plant varieties: the seed companies. Since the seed companies do not in order to secure rights under UPOV have to add an inventive step, it is literally an open invitation to these companies to appropriate a plethora of rights to themselves, leaving farmers with very little. Although farmers under UPOV may still be able to grow and save their seeds, they will be unable to share in the benefits of the commercial exploitation of the seeds that they have helped to differentiate and to preserve.

These concerns have been raised by developing countries, notably India, which has a large percentage of subsistence farmers. Of particular importance to them is the fact that UPOV permits dual protection of plant varieties; it entails that the same variety can be protected by Plant Breeders' Rights (PBR) as well as by patents. ${ }^{107}$ It is feared that such a mechanism as PBR will be used to obtain patent protection for varieties that fail to meet the patent criteria (inventiveness and usefulness). It is further argued that the UPOV system, which involves elaborate testing and approval prior to the award of a UPOV certificate, is far too expensive for the average small

\footnotetext{
$99 \quad$ Ibid., Article 7.

100 Ibid., Article 8.

101 Ibid., Article 9.

102 Hassemer, Michael, "Genetic resources", in von Lewinski, op. cit., n. 88 at 172.

103 UPOV Convention 1991, Article 15(1).

104 Hassemer, loc. cit., n. 102, at 174.

105 Ibid., at 175.

106 Ibid.

107 Gene Campaign, Why India/Developing Countries Need an Alternative to UPOV (New Delhi, Gene Campaign, 1998).
} 
company, farmers' co-operative or farmer/breeder. This will leave the area of the market open to the large seed companies who have the financial capability to make such heavy investments. Such a system, it is argued, will cause the farmers to sell their varieties for a pittance to the large seed companies, who would in turn exploit them for huge returns. ${ }^{108}$

Further, there is dissatisfaction with the way countries have sought to incorporate UPOV standards into local legislation. Scholars believe that government entities in developing countries have not incorporated UPOV provisions into local law in a manner that benefits farmers, while those in developed countries have been able to extract the maximum possible advantage from such instruments. ${ }^{109}$ It has also been noted that in many instances no provisions have been made in domestic law with regard to rights over crop wild relatives, traditional crop varieties, or newly developed crop varieties already in the public domain. ${ }^{110}$ There is no way in which farmers could be compensated in cases where one or more of these are employed to create a new variety which would then be protected by a breeder's right. In such an event, it could result in the farmer who nurtured the original variety paying a fee for the use of the derived crop.

It is interesting to note that the proponents of UPOV as a viable alternative to be used in determining a sui generis system appear to be Western scholars, while the opposition to UPOV stems from the developing world. ${ }^{111}$ Part of the problem seems to be that the developed world cannot conceive of the farmer as being anything but a farmer. Many may envision the farmer as a village yokel, engaging in the routine and monotonous task of ploughing the field from morning to night. The developing world accords the farmer greater respect, and understands that he plays an important part in conserving and promoting biodiversity. Sahai points out that

[W] e need to overcome the bias that most of us suffer from, that of acknowledging the research conducted by scientists in white coats working in laboratories of universities as "Science" and dismissing the complex knowledge systems contained in rustic, rural communities as something infinitely less and not worthy of acknowledgement. ${ }^{12}$

\subsubsection{Alternative possibilities: CoFab as an option}

\footnotetext{
108 Ibid.

109 Gunawardene, op. cit., n. 3, at 3, highlights the fact that the USA, Australia, and the EU have incorporated the "farmers" privilege" as a mandatory right, while the Draft Sri Lankan Act to Protect New Plant Varieties has relegated it to the position of an option, to be decided by the Minister in charge of the subject.

110 Ibid.

111 The contributors to von Lewinski's book are from European nations. Gene Campaign and Gunawardene are Indian and Sri Lankan respectively. Watal, though originally from India, has been in the USA for some time. Consequently, her views take a middle path, advocating the pursuit of Western standards as a matter of necessity, rather than of choice.

112 Sahai, op. cit., n. 1, at 132.
} 
One of the options that might be considered to fill the vacancy created by the sui generis requirement is the Convention on Farmers and Breeders $(\mathrm{CoFaB}){ }^{113}$ This was drafted in New Delhi in 1998, at the initiation of Gene Campaign. ${ }^{114}$ It has been proposed as an alternative to UPOV, and is presented as a forum for implementing Farmers and Breeders' rights in developing countries. Article 5 specifies the rights of farmers and breeders; Article 5 (1) proposes that the farming community be entitled to a fee from breeders every time a landrace or traditional variety is used for the purpose of breeding or improving a new variety. Article 5(2) proposes that breeders be entitled to the right to authorize the commercial exploitation of the plant variety that they have bred. Article 5(4) reserves to the contracting parties the right to legislate in a manner that increases the scope of the breeders' rights, especially with regard to marketing rights.

While $\mathrm{CoFaB}$ appears to be the only text that recognizes, and rewards, traditional communities for their rights over intellectual property, it is also the text with the lowest amount of influence. It is only a proposed treaty, and has no legal effect whatsoever. However, it demonstrates the standard that developing countries want to set, and could be useful in future negotiations on a possible amendment to Article 27 (3) (b) of TRIPS.

\subsubsection{Securing rights through contracts}

It has also been proposed that contracts, conducted in good faith, are the most practical answer to the problem of trying to reconcile intellectual property rights of the formal and informal natures. ${ }^{115}$ A contract, since it is tailor-made, could address the issues that both parties think is most important, and specify the rights and obligations only to the extent to which the parties feel comfortable. However, given the vast disparity between the parties with regard to economic influence, access to information and, consequently, all-important bargaining power, this will also fail to function well, as it will result in the farmers' suffering the raw end of the deal.

\subsubsection{Projections for the future}

Bio-technology is the tool of the future. There are vast possibilities for enrichment in this field; hence, developing nations should ultimately seek to reap the rewards of bio-technology. Further, if the vast numbers of subsistence farmers in these countries are to survive in the modern era, it becomes imperative for them to do so. It has been suggested that developing nations should identify the development of competitive skills in research in bio-technology as an important policy objective. ${ }^{116}$ However, given the technological gap between developed and developing countries,

\footnotetext{
113 http://www.genecampaign.org.

114 An Indian Non-Governmental Agency specializing in Intellectual Property, Genetic Resources and Indigenous Communities. See http://www.genecampaign.org.

115 Watal, op. cit., n. 9, at 177.

116 Ibid., at 183.
} 
collaboration, not confrontation, has been offered as the means by which this is to be achieved. Watal suggests that developing nations open up their IPR laws and allow for greater protection, while attempting to raise themselves to the standard where they can conduct independent research, develop sound R\&D bases, and implement a strong IPR regime to protect them.

This line of reasoning ignores a fundamental factor crucial to the debate: that of occupying the field. By the time developing nations acquire the know-how required to protect their indigenous knowledge, most of it would no longer be indigenous, and would probably long before have been patented by the developed world. Also by that time, the traditional communities that originally owned the knowledge would find they could no longer apply it. This is particularly true in an era when knowledge is becoming increasingly ephemeral, and today's discovery is tomorrow's waste.

\section{CONCLUSION}

When compared with the problems that arose with regard to pharmaceutical companies, the bio-technological area seems to be better prepared. While the pharmaceutical sector waited until the AIDS crisis arose before they began seeking solutions, debate and proposals for reform have been going on in the pharmaceutical sector since the 1990s. Part of the reason may be that entire communities stand to lose their livelihoods in these largely agricultural nations, hence the threat, as well as the consequences, are substantial, to say the least. It is true that developing nations must raise themselves into a position where they too can reap the benefits of bio-technology. It is, however, also true that developing nations need to protect the wealth of knowledge they possess until such time as they are able to harness it. While building up R\&D can take years, even decades, developing good legal regimes can be accomplished in a relatively shorter time.

It is submitted that, as at least a short-term solution, developing nations should identify their priorities and enact legislation to protect the local communities and repositories of Intellectual Property. If government entities lack the requisite knowledge, they should work in conjunction with non-governmental entities, which appear to be far better aware of the thorny issues involved. While TRIPS provides no adequate protection, the ambiguity of its language (especially that in relation to sui generis methods of protection) better advantage could have been taken of this factor by developing nations, who are, after all, free to adopt their method of choice. The fact that they have not chosen to do so is squarely their fault.

A key question to have emerged is whether discussions on these subjects have developed far enough for them to be handled immediately in the WTO, or whether members should wait until technical discussions in the WIPO are resolved. ${ }^{117}$ The topic should be addressed before it escalates any further. Traditional communities

117 TRIPS: Reviews, Article 27.3(B) and Related Issues. http://www.wto.org/english/tratop_e/trips_e/ art27_3b_background_e.htm 
have shouldered the burden of maintaining the diversity of the crops that sustain us all this while. We must not fail them now. 